\title{
TAX GOVERNANCE AS A PART OF CORPORATE SOCIAL RESPONSIBILITY
}

\author{
Natalja Verina $^{1}$, Jelena Titko ${ }^{2}$, Ilona Lejniece ${ }^{3}$ \\ $1,2,3$ University of Economics and Culture, Lomonosova 1/5, Riga, Latvia \\ E-mails: ${ }^{1}$ natalja.verina@inbox.lv; ${ }^{2}$ jelena.titko@eka.edu.lv (corresponding author); \\ 3lejniece.ilona@gmail.com
}

\begin{abstract}
Nowadays, responsible business conduct and corporate social responsibility (CSR) prioritized at the governmental level. Even more and more companies now report on CSR. Financial transparency, in particular responsible tax governance considered to be as a part of CRS. Authorities propose to update CRS guidelines and involve guidance on responsible tax policies. The goal of the current research was to was get an insight into the understanding of CSR by Latvian business sector representatives with the particulat focus on tax management issues. Representatives of Latvian companies from different sectors of economy were surveyed, using the authors' developed questionnaire. The respondents were offered to evaluate a range of statements regarding the understanding of the CSR concept as a combination of diffrenet elements, the awareness of the European Parliament's Directive on disclosure of non-financial information, as well as attitude to tax management in the framework of CSR. The results of the given research provide a platform for further investigation in the field of CSR in Latvian business environment.
\end{abstract}

Keywords: corporate social responsibility, tax governance, non-financial reporting, survey, business sector, Latvia.

JEL Classification: M14.

\section{Introduction}

Based on the view point of OECD experts "Paying tax into public finances is clearly part of how business contributes to society... Today we see that paying tax is already being looked at as an element of corporate responsibility" (Scheiwiller \& Symon, 2017).

The current research was inspired by the fact that there is no consensus between researchers and experts regarding tax management as a part of CSR. The idea of the current research was also supported by the implemented European directive regarding the disclosure of non-financial information - Directive 2014/95/EU (European Parliament, 2014). $62 \%$ of respondents participated in the CSR managers survey 2015 in Central Europe (Delloite, 2015) agreed on the statement that the Directive wil positively impact he quality of nonfinancial reporting in their country. However, the implementation of the Directive raised many questions from business counterparties about the information required in non-financial reports. Considering tax management as a part of CSR business practice, it should clear what information regarding tax-related activities should be disclosed by the companies.
The goal of the paper is to contribute to the field of CSR-related issues in the context of tax management. The current research is aimed to reveal the CSR awareness gap among entrepreneurs. The following task should be accomplished: (1) to evaluate the level of understanding of the CSR concept within Latvian business environment, and (2) to analyse the opinions of business sector representatives about CSR elements related to tax management issues.

The research hypothesis is stated, as follows:

H1: Business sector representatives in Latvia do not consider tax management issues as an essential part of CSR-oriented practice.

To test the hypothesis representatives of Latvian companies were surveyed, using the authors' developed research instrument. 38 respondents provided fully completed questionnaires. Frequency analysis was performed to make conclusions, based on respondents' answers.

The results of the research point to the lack of awareness about tax management issues as a part of business socially responsible behaviour among Latvian entrepreneurs. Most of them consider tax paying as an integral CSR element rather than tax information disclosure even though it should be considered as a regulatory requirement mostly. 


\section{Tax management and corporate social responsibility}

For the first time, the term "social responsibility of business" was introduced by American economist Howard Bowen (1953).

Nowadays, CSR is defined as:

- a concept whereby business organizations consider the interest of society by taking responsibility for the impact of their activities on customers, suppliers, employees, shareholders, communities and other stakeholders as well as their environment (Ismail, 2009);

- the continuing commitment by business to behave ethically and contribute to economic development while improving the quality of life of the workforce and their families as well as of the local community and society at large (WBCSD, 1998);

- an integrated strategic, ethical, social, and environmental concerns, on a voluntary basis, in business operations and in companies' interaction with their stakeholders (Barin \& Boehe, 2008);

- the set of practices and behaviours that firms adopt towards their labour force, towards the environment in which their operations are embedded, towards authority and towards civil society (Foran, 2001).

The most capacious and accurate, in our opinion, is the definition provided by the Australian Centre for Corporate Social Responsibility (ACCSR, 2018): "Social responsibility is the responsibility of an organisation for the impacts of its decisions and activities on society and the environment, through transparent and ethical behaviour that: (i) contributes to sustainable development, including the health and the welfare of society; (ii) takes into account the expectations of stakeholders; (iii) is in compliance with applicable law and consistent with international norms of behaviour, and (iv) is integrated throughout the organization and practised in its relationships".

CSR definitions differ widely due to the multidimensional nature of concept. Besides, different souces suggest various CSR dimensions (Johnson \& Greening, 1999; Kocmanova \& Simberova, 2012; Dahlsrud, 2008; Van Marrewijk, 2003 and others), such as:

- environmental dimension;

- economic dimension;

- community/ social dimension.
The economic dimension of CSR consider "direct and indirect economic impacts that the organization's operations have on the surrounding community and on the company's stakeholders." (Uddin, Tarique, \& Hassan, 2008)

The environmental dimension refers to the natural environment and sustainability of business practice (Stojanovic, Mihajlović, \& Schulte, 2016).

The social dimension of CSR includes such elements, as (i) the health, safety and general wellbeing of employees; (ii) motivation of the workforce by offering training and development opportunities; (iii) creating a formal social dialogue to take into account stakeholders' interests; (iv) relationship between business and society in general (Laguir, Staglianò, \& Elbaz, 2015; Stojanovic et al. 2016).

Despite the fact that CSR concept involves many and various components, tax-related issues are not mentioned so frequently as CSR part. However, last years the attention to this topic has been increased.

Citing Holme and Watts (1999), "Corporate Social Responsibility is the continuing commitment by business to behave ethically and contribute to economic development while improving the quality of life of the workforce and their families as well as of the local community and society at large". This indirectly indicates to the link between CSR and tax paying by the companies.

Jenkins and Newell (2013) stated that "there are many parallels between tax and mainstream CSR issues such as labour rights and environmental sustainability".

Many scholars pay attention to the relationship between business ethical behavior and tax avoidance (Huseynov \& Klamm, 2012; Hoi, $\mathrm{Wu}$, \& Zhang, 2013; Ylönen \& Laine, 2015).

CSR questions in the field of taxation are considered to be important also by business community. In 2014-2017 many Danish companies participated in the survey "The Tax Dialogue - on corporate responsibility" (IBIS, 2017). The main conclusions drawn from the survey were: (i) the majority of respondents believe tax is a corporate responsibility and even more have a corporate tax policy, and (ii) there are no consistent references to CSR guidelines and frameworks in the tax policies, which suggests the established systems provide little operational support".

The representatives of the Confederation of SweTo achieve the research goal and to test the research hypothesis, an authors' developed questionnaire was distributed among Latvian business 
sector representatives. The questionnaire involved four comprehensive questions (Table 1), as well as respondent profile section.

dish Enterprise state that "it is important to adopt a realistic and nuanced approach to including taxes in CSR" (Svernlov \& Osterman, 2016).

The current research is an attempt to get an insight into understanding of tax management issues as integral part of CSR among Latvian entrepreneurs.

\section{Research design and methodology}

At the initial stage of the research the simplified content analysis of the definitions of the concept "corporate social responsibility and CSR-related text segments" was conducted. Information data base included 22 text extracts from English language sources and 21 definitions and text segments from Latvian sources (Andersen, 2003; Foran, 2001; International Institute for Sustainable Development, 2018; McWilliams, Siegel, \& Wright, 2006; Barin \& Boehe, 2008; Manne \& Wallich, 1972; Blowfield \& Murray, 2008; Carroll, 1991; Hopkins, 2003; Frederick, Post, \& Davis, 1992; Lea, 2003; Wood, 1991; KPMG JSC, 2011; Ministry of Welfare of the Republic of Latvia, 2018; Latvenergo, 2018; Grindex, 2018; Iecavnieks, 2018; Nordea, 2018; Statoil, 2018; Olympic casino, 2018; Fazer, 2018; European Business Support Network in Latvia, 2018; Sorainen, 2018; Grifs, 2018; Latvijas Balzams JSC, 2018; If, 2018; Domuss, 2018; Skrivanek, 2018; LDz, 2018; Certex, 2018; Moller Auto, 2018; Employers' Confederation of Latvia, 2018; Vives, 2004; Visser, Matten, Pohl, \& Tolhurst, 2010; European Commission, 2001, 2018a, 2018b; Portney, 2005; Ness, 1992; Financial Times lexicon, 2018; WBCSD, 1998; WBCSD, 2018).

Table 1. Structure of the research questionnaire (source: authors' development)

\begin{tabular}{|l|l|}
\hline \multicolumn{1}{|c|}{ Question } & \multicolumn{1}{c|}{ Details } \\
\hline $\begin{array}{l}\text { Q1_1- } \\
\text { Q1_11 }\end{array}$ & $\begin{array}{l}\text { Understanding of CSR concept. 11 } \\
\text { statements about the core of CSR. }\end{array}$ \\
\hline Q2 & $\begin{array}{l}\text { Awareness about the Directive } \\
\text { 2014/95/EU }\end{array}$ \\
\hline Q3 & $\begin{array}{l}\text { Tax information in non-financial } \\
\text { reporting }\end{array}$ \\
\hline Q4_1-Q4_4 & $\begin{array}{l}\text { Attitude to tax management as a part } \\
\text { of SCR }\end{array}$ \\
\hline $\begin{array}{l}\text { Respondent } \\
\text { Profile }\end{array}$ & 4 questions \\
\hline
\end{tabular}

To achieve the research goal and to test the research hypothesis, an authors' developed questionnaire was distributed among Latvian business sector representatives. The questionnaire involved four comprehensive questions (Table 1), as well as respondent profile section.

The labels for the Q1 statements offered to the respondents for evaluation are summarised in the Table 2.

Table 2. Labels for the statements in the questionnaire (source: authors' development)

\begin{tabular}{|c|c|c|}
\hline Q & Statement & Label \\
\hline Q1_1 & $\begin{array}{l}\text { Activities towards providing } \\
\text { of the customers' well-be- } \\
\text { ing (improving/maintaining } \\
\text { product/services quality and } \\
\text { etc.) }\end{array}$ & $\begin{array}{l}\text { Customers } \\
\text { well-being }\end{array}$ \\
\hline Q1_2 & Respect to customers' rights & $\begin{array}{l}\text { Customers } \\
\text { rights }\end{array}$ \\
\hline Q1_3 & $\begin{array}{l}\text { Activities towards providing } \\
\text { of the employees' well-be- } \\
\text { ing (wage payments in time } \\
\text { and in full amount, social } \\
\text { guarantees and etc.) }\end{array}$ & $\begin{array}{l}\text { Employees } \\
\text { well-being }\end{array}$ \\
\hline Q1_4 & $\begin{array}{l}\text { Maintaining of safe and } \\
\text { healthy environment for } \\
\text { employees }\end{array}$ & $\begin{array}{l}\text { Safe and } \\
\text { healthy work }\end{array}$ \\
\hline Q1_5 & $\begin{array}{l}\text { Providing professional } \\
\text { training and development } \\
\text { opportunities for employees }\end{array}$ & Staff training \\
\hline Q1_6 & $\begin{array}{l}\text { Activities towards reducing } \\
\text { pollution or avoiding pollu- } \\
\text { tion-rising activities }\end{array}$ & $\begin{array}{l}\text { Pollution } \\
\text { avoiding }\end{array}$ \\
\hline Q1_7 & $\begin{array}{l}\text { Producing (selling) of envi- } \\
\text { ronment-friendly/ eco-prod- } \\
\text { ucts or eco-services }\end{array}$ & $\begin{array}{l}\text { Eco-products/ } \\
\text { services }\end{array}$ \\
\hline Q1_8 & $\begin{array}{l}\text { Charity, participation in so- } \\
\text { cial projects }\end{array}$ & Charity \\
\hline Q1_9 & $\begin{array}{l}\text { Shareholders' satisfaction } \\
\text { (shareholder long-term } \\
\text { value maximization and } \\
\text { etc.) }\end{array}$ & $\begin{array}{l}\text { Shareholders' } \\
\text { satisfaction }\end{array}$ \\
\hline Q1_10 & $\begin{array}{l}\text { Fulfillment of obligations to } \\
\text { government and society a s } \\
\text { a whole (tax payments in } \\
\text { time and in full amount) }\end{array}$ & $\begin{array}{l}\text { Obligations to } \\
\text { government } \\
\text { and society }\end{array}$ \\
\hline Q1_11 & $\begin{array}{l}\text { Providing work places for } \\
\text { citizens with special needs }\end{array}$ & $\begin{array}{l}\text { Providing } \\
\text { work places } \\
\text { for citizens } \\
\text { with special } \\
\text { needs }\end{array}$ \\
\hline
\end{tabular}

To assess the awareness of Latvian business sector representatives about CSR concept, they 
were offered to evaluate the statements about company's business activities in terms of their connection to CSR, using 5-point scale (1 - it is not related to CSR; 5 - it is one of the essential CSR elements/ related activities). Separately, respondents were offered additional statements about tax management activities to evaluate in the same manner. Besides, there was the question regarding the awareness about the Directive 2014/95/EU (informed/not informed) and the question about the place of tax management information in non-financial report.

38 respondents participated in the survey. Sample was distributed, as follows:

- Most represented business sectors were (1) transport services, (2) finance and insurance, and (3) recreation and entertainment.

- $81 \%$ of respondents represented companies with the number of employees less than 250 . There were no representatives of the companies with over 500 staff members.

- Distribution of the respondents represented micro-companies, SMEs and large companies was $41 \%, 41 \%$ and $16 \%$, respectively.

- $58 \%$ of respondents answered that their company does not prepare CSR report. However, several companies do or plan to be engaged in CSR reporting (18\% and $18 \%$, respectively).

Some of respondents did not provide data within the profile section.

To answer Q1 ("What is your understanding of the concept "Corporate Societal Responsibility (CSR)"? In your opinion, which business activities are related to CSR?" and Q4 ("Considering tax management as a part of CSR, please, evaluate each of the tax management activities") the respondents were offered to use 5-point scale, where "1-2" indicated a low association between the activities and CSR, but " 3 " and " $4-5$ " - average and strong association, respectively.

Frequency analysis was performed to analyse respondents answers. Due to the limited number of respondents the analysis of answers' distribution depending on profile criteria was not performed.

\section{Results}

Frequency table was generated to reveal the most often mentioned elements (Table 3 ).
Table 3. Elements of the CSR concept: frequency analysis results

\begin{tabular}{|l|c|}
\hline \multicolumn{1}{|c|}{ Word (ENG) } & Frequency \\
\hline Environment (-al) & 48 \\
\hline Development & 12 \\
\hline Employees & 16 \\
\hline Society / Community & 46 \\
\hline Sustainable & 11 \\
\hline Ethical & 5 \\
\hline Stakeholders (customers) & 18 \\
\hline Safety & 5 \\
\hline Quality & 4 \\
\hline Charity & 4 \\
\hline
\end{tabular}

Frequency analysis based on the content analysis of 44 CSR-related text segments revealed the fact that tax-related elements are not frequently mentioned by scholars and experts (zero result in this case). It means that tax-management issues are still not considered as a CSR part.

Respondents' answers to the question Q1 are summarised in the Table 4.

Table 4. Evaluation of company's activities in terms of their association with CSR (source: authors' compilation) (source: authors' compilation)

\begin{tabular}{|l|c|c|c|}
\hline \multicolumn{1}{|c|}{ Activity } & Low & Average & Strong \\
\hline $\begin{array}{l}\text { Customers' well-be- } \\
\text { ing }\end{array}$ & $16 \%$ & $45 \%$ & $39 \%$ \\
\hline Customers rights & $8 \%$ & $42 \%$ & $50 \%$ \\
\hline $\begin{array}{l}\text { Employees' well-be- } \\
\text { ing }\end{array}$ & $5 \%$ & $34 \%$ & $61 \%$ \\
\hline Safe and healthy work & $3 \%$ & $29 \%$ & $68 \%$ \\
\hline Staff training & $11 \%$ & $50 \%$ & $39 \%$ \\
\hline Pollution avoiding & $5 \%$ & $26 \%$ & $68 \%$ \\
\hline $\begin{array}{l}\text { Eco-products/ ser- } \\
\text { vices }\end{array}$ & $8 \%$ & $39 \%$ & $53 \%$ \\
\hline Charity & $16 \%$ & $26 \%$ & $58 \%$ \\
\hline $\begin{array}{l}\text { Shareholders' } \\
\text { satisfaction }\end{array}$ & $26 \%$ & $39 \%$ & $34 \%$ \\
\hline $\begin{array}{l}\text { Obligations to gov- } \\
\text { ernment and society }\end{array}$ & $16 \%$ & $39 \%$ & $45 \%$ \\
\hline $\begin{array}{l}\text { Providing work places } \\
\text { for citizens with spe- } \\
\text { cial needs }\end{array}$ & $5 \%$ & $45 \%$ & $50 \%$ \\
\hline
\end{tabular}

The business activities having a strong association with CSR in the opinion of most of the respondents were: (i) "pollution avoiding", "safe and healthy work" and "employees' well-being". In turn, "shareholders' satisfaction", "staff training" and "customers' well-being" were perceived 
as CSR-related by the quite lower number of respondents.

Answering the question Q2 regarding the awareness about the Directive 2014/95/EU, 12 of 38 respondents declared that they have the information about the Directive and they understand its content. However, 19 respondents are not informed about the document.

Answering the question Q3 ("Whether the Directive 2014/95/EU it requires inclusion of information about tax policy and tax management into the non-financial report?") half of respondents, predictably, did not have a specific opinion on the matter, but 10 respondents answered that according to their understanding of the Directive it is not assumed to include tax management information into the report.

However, analysing the answers on Q4 question (Table 5), it could be concluded that the respondents did not really understand the comprehensive nature of tax management, because evaluating separate tax management activities many respondents associated them with CSR.

Table 5. Evaluation of the tax management activities in terms of their association with CSR (source: authors' compilation)

\begin{tabular}{|l|c|c|c|}
\hline \multicolumn{1}{|c|}{ Activity } & Low & Average & Strong \\
\hline $\begin{array}{l}\text { Social payments in } \\
\text { time and in a full } \\
\text { amount }\end{array}$ & $11 \%$ & $29 \%$ & $61 \%$ \\
\hline $\begin{array}{l}\text { Avoiding income ma- } \\
\text { nipulation }\end{array}$ & $13 \%$ & $45 \%$ & $42 \%$ \\
\hline $\begin{array}{l}\text { Information disclosure } \\
\text { about the tax policy }\end{array}$ & $24 \%$ & $47 \%$ & $29 \%$ \\
\hline $\begin{array}{l}\text { Information disclosure } \\
\text { about the amounts of } \\
\text { tax payments }\end{array}$ & $29 \%$ & $37 \%$ & $34 \%$ \\
\hline
\end{tabular}

Unambiguous conclusion can be made regarding the accociation between CSR and the statement "social payments in time and in a full amount". However, this is an activity that is required by Latvian law and, actually, it does not refer to CSR directly. In turn, only $29 \%$ of respondents admit the strong link between "information disclosure about tax policy" and socially responsible business behaviour. We assume that the explanation is in the low awareness about the importance of the information disclosure among Latvian business sector representatives.

\section{Conclusions}

The current research is the authors' attempt to fill the scientific gap in the field of Tax managementCSR studies. It is still new topic for researchers, but in Latvia we did not find the similar inquiries at all.

Conducting the survey, the authors of the given paper received a comprehensive remark from one of the prospective respondents. The brief translation is, as follows: “... even being engaged for the long-term into CSR-related activities in the Latvian Employers' Confederation and State Enterprise "Latvijas dzelzcel̦š" [Latvian Railway], as well as cooperating with the experts of the Institute of Corporate Sustainability and Responsibility, I cannot fill this questionnaire qualitatively. The reason is that on my opinion and on the opinion of the above mentioned experts, paying taxes is not CSR/Sustainability aspect. The core of social responsibility is what companies do over the minimum regulatory requirements, while tax paying is a statutory obligation for any company. That is why I cannot fill this questionnaire, because the questions included did not provide an opportunity to express my opinion".

The developed questionnaire involved not only the questions and statements related to the tax paying issues. However, most of business sector representtaives do not perceive any tax-related statements as something connected with CSR activities.

The research hypothesis "Business sector representatives in Latvia do not consider tax management issues as an essential part of CSR-oriented practice." was partially confirmed. Only $45 \%$ of respondents see the strong relationship between CSR-oriented business practices and "fulfillment of obligations to government and society as a whole (tax payments in time and in full amount)".

The main limitation of the current research is the number of respondents that certainly should be enlarged. The problem in this regard is the inactivity and unwillingness of the business sector representatives to participate in any kind of surveys. It is extremely difficult to collect the answers from the respondents. Sometimes it is possible only using the network of personal contacts.

Latvian entrepreneurs associate corporate social responsibility mostly with the pollution avoidance, as well as with the well-being of their staff members that also connected with the safe and healthy business environment. It is interesting that among all the stakeholder groups employees are prioritised, while well-being of customers and 
shareholders is evaluated as least associated with CSR.

The results regarding "pollution avoidance" are also suprising. Indeed, 68\% respondents evaluated the relationship between pollution avoidance and CSR as "strong", but actually this percent should be closed to $100 \%$. Environmental aspect is the most commonly mentioned CSR element at a glance.

Considering that tax management issues are admitted to be a part of business CSR practices, it is necessary to increase awareness about this aspect among business representatives, not only in Latvia and Baltics, but also in other countries.

The results of this survey can be used as a platform for further investigation of the topic. The research instrument can be easily adapted for a survey in any country, or even can be used without amendments. The survey definitely should be continued in Latvia and Baltics as well. Probably, the best solution is to organize personal interviews with the respondents. The overall impression from the analysis of the answers is that sometimes they are inconsistent that points to the lack of understanding among the participants. This, in turn, usually yield non-reliable results, because the respondents choose the answers at random.

One of the possible directions for further study in the CSR field could be the investigation of the relationship between Latvian (or Baltic region) business engagement into CSR practices and its economic performance. This topic is quite popular among the scholars - however, there is no contribution from the researchers representing Latvia or neighbour countries.

\section{Disclosure statement}

The authors do not they have any competing financial, professional, or personal interests from other parties.

\section{References}

ACCSR. (2018). What is CSR? Retrieved from http://accsr.com.au/what-is-csr/

Andersen, KI. (2003). The project. Retrieved from http://www.aiesec.dk/projects/rexpect/Theproject.htm\#Definition

Barin Cruz, L., \& Boehe, D. M. (2008). CSR in the global marketplace: towards sustainable global value chains. Management Decision, 46(8), 1187-1209. https://doi.org/10.1108/00251740810901381

Blowfield, M., \& Murray, A. (2008). Corporate responsibility: a critical introduction. Oxford: Oxford University Press.

Bowen, H. R. (1953). Social responsibility of the business. Californian Management Review, 18(3), 49-58.
Carroll, A. B. (1991). The pyramid of corporate social responsibility: toward the moral management of organizational stakeholders. Business Horizons, 34(4), 39-48. https://doi.org/10.1016/0007-6813(91)90005-G

Certex, JSC. CSR. (2018). Corporate social responsibility. Retrieved from http://www.certex.lv/lv/atbildiba

Dahlsrud, A. (2008). How corporate social responsibility is defined: an analysis of 37 definitions. Corporate Social Responsibility and Environmental Management, 15(1), 1-13. https://doi.org/10.1002/csr.132

Delloite. (2015). CSR managers survey 2015 in Central Europe: how CSR has influenced Central European societies and economies. Lessons leant and future trends. Retrieved from https://www2.deloitte.com/content/dam/Deloitte/pl/Documents/Reports/pl_CSR Managers_Survey_2015_in_Central_Europe_ENG_ 2016.pdf

Domuss, JSC. (2018). Corporate social responsibility. Retrieved from http://domuss.lv/lv/par_mums/korporativa_sociala_atbildiba/

Employers' Confederation of Latvia. (2018). Corporate social responsibility platform. Retrieved from http://en.lddk.lv/pakalpojums/a-corporate-social-responsibility-platform/

European Commission. (2018a). Corporate social responsibility in the European Union. Retrieved from http://ec.europa.eu/social $/$ main.jsp? catId $=331$ \&langId $=1 \mathrm{v}$

European Business Support Network in Latvia. (2018). Corporate social responsibility - foundation for modern and sustainable entrepreneurship. Retrieved from file:///C:/Users/Nata/Downloads/FaktuLapa_KSI.pdf

European Commission. (2001). Directorate-General for Employment. Promoting a European Framework for Corporate Social Responsibility: Green Paper. Office for Official Publications of the European Communities.

European Commission. (2018b). Corporate social responsibility. Retrieved from http://ec.europa.eu/growth/industry/corporate-social-responsibility_en

European Parliament. (2014). Directive 2014/95/EU of the European Parliament and of the Council (22.10.2014). Official Journal of the European Union, L330(1). Retrieved from https://eur-lex.europa.eu/legal-content/EN/TXT/PDF/?uri=CELEX:32014L0095\&from= EN

Fazer, JSC. (2018). Social responsibility. Retrieved from http://www.fazer.lv/par-fazer/socil-atbildba/

Financial Times lexicon. (2018). Retrieved from http://lexicon.ft.com/Term?term=corporate-social-responsibility--(CSR)

Foran, T. (2001). Corporate Social Responsibility at nine multinational electronics firms in Thailand: a preliminary analysis, Report to the California Global Corporate Accountability Project. Nautilus Institute for Security and Sustainable Development: Berkeley, CA.

Frederick, W. C., Post, J., \& Davis, K. E. (1992). Business and society. Corporate strategy, public policy, ethics (7th ed.). London: McGraw-Hill.

Grindex, J. S. C. (2018). Corporate social responsibility. Retrieved from http://www.grindeks.lv/lv/par-grindeks/korporativa-sociala-atbildiba

Grifs, J. S. C. (2018). Corporate social responsibility. Retrieved from http://www.grifsag.lv/sociala-atbildiba/

Hoi, C. K., Wu, Q., \& Zhang, H. (2013). Is corporate social responsibility (CSR) associated with tax avoidance? Evidence from irresponsible CSR activities. The Accounting Review, 88(6), 2025-2059.

https://doi.org/10.2308/accr-50544 
Holme, R., \& Watts, P. (1999). Corporate social responsibility. Geneva: World Business Council for Sustainable Development.

Hopkins, M. (2003). The planetary bargain-CSR matters. London: Earthscan.

Huseynov, F., \& Klamm, B. K. (2012). Tax avoidance, tax management and corporate social responsibility. Journal of Corporate Finance, 18(4), 804-827. https://doi.org/10.1016/j.jcorpfin.2012.06.005

IBIS. (2017). Tax-a corporate responsibility priority: mapping the policies and practicies of major Danish investors and companies. Retrieved from http://thetaxdialogue.org/sites/default/files/PDF\%20global/the tax di alogue_mapping_report2014.pdf

Iecavnieks, J. S. C. (2018). Corporate social responsibility. Retrieved from http://www.iecavnieks.lv/lv/korporativa-atbildiba

If, JSC. (2018). Corporate social responsibility. Retrieved from https://www.if.lv/web/lv/parif/parmums/ksa/ pages/start.aspx

International Institute for Sustainable Development. (2018). Retrieved from https://www.iisd.org/business/issues/sr.aspx

Ismail, M. (2009). Corporate social responsibility and its role in community development: an international perspective. The Journal of International Social Research, 2(9), 199-209.

Jenkins, R., \& Newell, P. (2013). CSR, tax and development. Third World Quarterly, 34(3), 378-396. https://doi.org/10.1080/01436597.2013.784596

Johnson, R. A., \& Greening, D. W. (1999). The effects of corporate governance and institutional ownership types on corporate social performance. Academy of Management Journal, 42(5), 564-576.

Kocmanova, A., \& Simberova, I. (2012). Modelling of corporate governance performance indicators. Engineering Economics, 23(5), 485-495.

Korporatīiā sociālā atbildība (Corporative Social Responsibility). (2018). Retrieved from http://www.liaa.gov.lv/ files/liaa/attachments/kapitals_liaa_12.pdf

KPMG, JSC. (2011). KPMG International Survey of Corporate Responsibility Reporting 2011.

Laguir, I., Staglianò, R., \& Elbaz, J. (2015). Does corporate social responsibility affect corporate tax aggressiveness?. Journal of Cleaner Production, 107, 662-675. https://doi.org/10.1016/j.jclepro.2015.05.059

Latvenergo, JSC. (2018). Corporate Social Responsibility. Retrieved from http://www.latvenergo.lv/lat/korporativa_sociala_atbildiba/

Latvijas Balzams, JSC. (2018). Corporate social responsibility. Retrieved from http://www.lb.lv/lv/uznemums/ sabiedriskas-aktivitates/

Employers' Confederation of Latvia. (2018). Corporative social responsibility platform. Retrieved from http://www.lddk.lv/pakalpojums/korporativas-socialas-atbildibas-platforma/

LDz (Latvijas dzelzcel̦š, JSC). (2018). About social responsibility. Retrieved from http://www.ldz.lv/lv/content/par-soci $\% \mathrm{C} 4 \% 81$ lo-atbild $\% \mathrm{C} 4 \% \mathrm{ABbu}$

Lea, R. (2003). Corporate social responsibility, Institute of Directors (IoD) member opinion survey. IoD: London. Retrieved from http://www.epolitix.com/data/companies/images/Companies/Institute-of-Directors/ CSR_Report.pdf
Ministry of Welfare of the Republic of Latvia. (2018). Corporate social responsibility. Available from Internet https://www.lm.gov.lv/text/753

Manne, H. G., \& Wallich, H. C. (1972). The modern corporation and social responsibility. Washington: American Enterprise Institute for Public Policy Research.

Moller Auto, JSC. (2018). Social responsibility. Retrieved from http://www.mollerauto.lv/Par-mums1/Korporatv-Socil-Atbildba/

McWilliams, A., Siegel, D. S., \& Wright, P. M. (2006). Corporate social responsibility: strategic implications. Journal of Management Studies, 43(1), 1-18. https://doi.org/10.1111/j.1467-6486.2006.00580.x

Ness, M. R. (1992). Corporate social responsibility. British Food Journal, 94(7), 38-44. https://doi.org/10.1108/00070709210019022

Nordea, JSC. (2018). Corporate social responsibility. Retrieved from http://www.nordea.lv/par+nordea/par+ nordea/korporat $\% \mathrm{C} 4 \% \mathrm{ABv} \% \mathrm{C} 4 \% 81+$ soci $\% \mathrm{C} 4 \%$ $811 \% \mathrm{C} 4 \% 81+$ atbild $\% \mathrm{C} 4 \% \mathrm{ABba} / 1563032 . \mathrm{html}$

Olympic Casino, JSC. (2018). Corporate social responsibility. Retrieved from http://www.olympic-casino.lv/ kompanija_lv/korporativa_sociala_atbildiba

Portney, P. R. (2005). Corporate social responsibility. Environmental protection and the social responsibility of firms-perspectives from law, Economics and Business, 4(39), 237-242.

Scheiwiller, T., \& Symon, S. (2017). Corporate responsibility and paying tax. Retrieved from http://www.oecdobserver.org/news/archivestory.php/aid/3132/Corporate_responsibility_and_paying_tax.html\#sthash.FeBv wOV̄g.dpuf

Sorainen, JSC. (2018). Corporate social responsibility. Retrieved from http://www.sorainen.com/lv/Par-mums/ Corporate-responsibility\#link1

Skrivanek, JSC. 2018. Corporate social responsibility. Retrieved from http://www.skrivanek.lv/lv/par-mums/ korporativa-sociala-atbildiba/

Statoil, JSC. (2018). Corporate social responsibility. Retrieved from https://www.statoil.lv/lv_LV/pg1334072 588793/par-Circle-K/Soci\%C4\%811\%C4\%81-atbild\% C4\%ABba.html

Stojanovic, A., Mihajlović, I., \& Schulte, P. (2016, May). Corporate social responsibility: environmental aspects. International May Conference on Strategic Management - IMKSM2016. Bor, Serbia. Retrieved from https://www.researchgate.net/publication/310773027 CORPORATE_SOCIAL_RESPONSIBILITY_ENVI RONMENTAL ASPECTS

Svernlov, K., \& Osterman, R. P. (2016). Corporate social responsibility and corporate taxation. Retrieved from https://www.svensktnaringsliv.se/migration_catalog/ Rapporter och opinionsmaterial/Rapporter/corporate_social_report_webbpdf_666655.html/BINARY/ Corporate_Social_report_webb.pdf

Uddin, M. B., Tarique, K. M., \& Hassan, M. (2008). Three dimensional aspects of corporate social responsibility. Daffodil International University Journal of Business and Economics, 3(1), 199-212.

Van Marrewijk, M. (2003). Concepts and definitions of CSR and corporate sustainability: between agency and communion. Journal of Business Ethics, 44(2-3), 95-105. https://doi.org/10.1023/A:1023331212247

Visser, W., Matten, D., Pohl, M., \& Tolhurst, N. (2010). The A to $Z$ of corporate social responsibility. Chippenham: John Willey \& Sons. 
Vives, A. (2004). The role of multilateral development institutions in fostering corporate social responsibility. Development, 47(3), 45-52.

https://doi.org/10.1057/palgrave.development. 1100065

Wood, D. J. (1991). Corporate social performance revisited. Academy of Management Review, 16(4), 691-718. https://doi.org/10.5465/amr.1991.4279616

WBCSD. (2018). World business council for sustainable development, CSR: meeting changing expectations. 2018.
Retrieved from http://www.wbcsd.org/work-program/business-role/previous-work/corporate-social-responsibility.aspx

WBCSD. (1998). World business council for sustainable development: Stakeholder Dialogue on CSR. The Netherlands.

Ylönen, M., \& Laine, M. (2015). For logistical reasons only? A case study of tax planning and corporate social responsibility reporting. Critical Perspectives on Accounting, 33, 5-23.

https://doi.org/10.1016/j.cpa.2014.12.001 